\title{
Does Separation Really Lead Fathers and Mothers to be Less Involved in their Children's Lives?
}

\author{
Michael Grätz \\ Nuffield College, University of Oxford \\ michael.gratz@nuffield.ox.ac.uk
}

Accepted for publication by the European Sociological Review on 7 June 2017.

\section{Acknowledgments}

The data used in this publication were made available to me by the German Socio-Economic Panel Study (SOEP) at the German Institute for Economic Research (DIW), Berlin. Earlier versions of this article were presented at the European Network for the Sociological and Demographic Study of Divorce conference in Paris in 2014, at the German Sociological Association meeting in Trier in 2014, and at the annual meeting of the Population Association of America in San Diego in 2015. I would like to thank participants at these meetings as well as Diederik Boertien, Jani Erola, Michael Gähler, Juho Härkönen, Eva-Lisa Palmtag, and Thorsten Schneider for their helpful comments and suggestions. 


\begin{abstract}
Parental separation is a disadvantageous life event with many consequences for the children who experience it. This article investigates the influence of parental separation on father and mother involvement in their children's lives in adolescence using data from the German Socio-Economic Panel Study (SOEP) and employing family fixed-effects models in order to control for omitted variable bias. The results show that parental separation negatively affects father involvement. Father involvement, however, is only reduced as a result of separation in socio-economically disadvantaged families. In addition, father involvement is more reduced for girls than for boys. Mother involvement is not influenced by parental separation. Taken together these results demonstrate that changes in parental involvement following parental separation show an important amount of heterogeneity.
\end{abstract}

\title{
Keywords
}

Postdivorce parenting; child/adolescent outcomes; parental investment/involvement; parentadolescent relations; within-family design 


\section{Introduction}

A large amount of research has shown that parental separation is associated with lower levels of child well-being and education (Amato, 2010). At least part of this association is due to a negative causal effect of parental separation on child outcomes (McLanahan, Tach and Schneider, 2013). The mechanisms underlying this causal effect, however, are less well understood. In particular, there is little research testing directly these mechanisms applying a research design which controls for omitted variable bias.

There are many possible unobserved variables which may confound the relationship between parental separation and involvement. For instance, parents who are less interested in fostering the development of their children may be more likely to separate. Another example of an unobserved variable is parental conflict which may lead to parental separation as well as negatively influence child development. It is unlikely that all possible sources of bias can be measured. Even in the unlikely case that these confounding variables could be measured, any measure would include a large amount of measurement error. Therefore, approaches which test the mechanisms underlying the parental separation penalty by conditioning on a number of control variables are unlikely to give an unbiased estimate of the causal effect of parental separation on these mechanisms.

In this article, I test whether parental separation affects parental involvement in their adolescent children. For this purpose I employ data from the German Socio-Economic Panel Study (SOEP) (Wagner, Frick and Schupp, 2007) and use family fixed-effects models to control for confounding through unobserved variables (Sandefur and Wells, 1999; Ermisch and Francesconi, 2001; Björklund and Sundström, 2006; Björklund, Ginther and Sundström, 2007; Francesconi, Jenkins and Siedler, 2010; Sigle-Rushton, Lyngstad, Andersen, Lie and Kravdal, 2014; Grätz, 2015). 
The parental resource perspective argues that changes in parental involvement following parental separation is one of the main mechanisms underlying the parental separation penalty (Coleman, 1988; Astone and McLanahan, 1991; Amato, 1993; Jonsson and Gähler, 1997; Gähler, Jonsson and Låftman, 2009). According to this view, the absence of one parent from the household leads to less parental involvement and, as a result, reduces child outcomes. The majority of children with divorced parents, however, reports to get along well with their father (Kalmijn 2015a). For that reason, parental separation may not necessarily lead to less parental involvement and testing whether this is the case is an important contribution to the literature on the consequences of separation.

The second aim of this article is to test for heterogeneity in parental separation effects (Amato, 2010). Several recent studies tested whether there is socio-economic variation in the association between parental separation and child education (Albertini and Dronkers, 2009; Augustine, 2014; Bernardi and Radl 2014; Grätz, 2015; Mandemakers and Kalmijn, 2014; Bernardi and Boertien, 2016). I test whether the effect of parental separation on parental involvement varies by family socio-economic background. In addition, I analyze variation in the effect of parental separation on parental involvement by child gender.

This study does not test whether a reduction in parental involvement following parental separation mediates the negative effects of parental separation on child outcomes for two reasons. First, the data used in the study measures parental involvement and children's educational outcomes at the same age of the children, making it impossible to identify the direction of causality. Second, mediation analysis relies on the assumption of sequential ignorability which is unlikely to be met (Imai, Keele, Tingley and Yamamoto, 2011). This study, however, provides an important first step in determining the role of parental involvement in explaining the parental separation penalty. If parental separation does not affect parental involvement, this mechanism cannot explain the negative effects of parental separation on child outcomes. 


\section{Background}

How and Why Parental Separation May Affect Parental Involvement

According to the parental resource perspective, parental separation leads not only to the physical separation between the child and one of the parents but also to a reduction in the involvement of that parent in the child's life and access to that parent's social capital which, in turn, leads to lower child outcomes (Coleman, 1988; Astone and McLanahan, 1991; Amato, 1993; Jonsson and Gähler, 1997; Gähler et al., 2009). This perspective makes two hypotheses in order to explain the negative effects of parental separation on child outcomes: First, it assumes that parental separation does affect parental involvement, and, second, it predicts that changes in parental involvement lead to changes in child outcomes. Support for the second assumption comes from research showing that higher levels of parental involvement are associated with more positive child outcomes (Harris, Furstenberg and Marmer, 1998; Yeung, Linver and Brooks-Gunn, 2002; Chan and Koo, 2011; Kaushal, Magnuson and Waldfogel, 2011). It is, however, less clear whether the first assumption holds. In most cases the frequency of contact between a child and the non-resident parent will go down following parental separation. It is, however, important to keep in mind that the parent who leaves the household, most often the father, may stay involved in the child's life (Amato, 1993). In many cases, he may have regular contact and a good relationship with the child (Kalmijn, 2015a). It is, therefore, important to distinguish between the quantity and the quality of father involvement.

The relationship between the resident parent, often the mother, and the child may be less negatively affected by separation. Certainly it could be that single mothers have to work more and have, hence, less time for the child (Astone and McLanahan, 1991). But there are also reasons to expect the relationship between mother and child to improve as a result of the 
separation. First, the mother could invest additionally in order to compensate for the loss of the other parent. Second, out of solidarity, the child's relation with the mother could improve.

Most studies which analyzed the parent-child relationship following parental separation measured the frequency of contact between the child and his/her parents (e.g. Furstenberg, Nord, Peterson and Zill, 1983; Seltzer and Bianchi, 1988; Mott, 1990; Seltzer, 1991; Cooksey and Craig, 1998; Amato and Gilbreth, 1999; King and Heard, 1999; Cheadle, Amato and King, 2010; Westphal, Poortman and van der Lippe, 2014). There are, however, several studies estimating the association between parental separation and the quality of parental involvement. Astone and McLanahan (1991) used a sample of sophomores in the United States in 1980. They measured parental practices based on student reports of parental college aspirations, monitoring of school progress, general supervision, and whether the child talked at least once a week with the parents. Children from single-parent families reported less parental monitoring and supervision but talked more often with their parents than children from two-parent families. Carlson (2006), using data on 10- to 14-years-old children in the United States, found that children with divorced parents had less often highly involved and more often low involved fathers, according to child reports, than children with continuously married or cohabiting parents. Chan and Koo (2011), using data on 15-years-old adolescents from the United Kingdom, argued that single-parent and two-parent families differed in the distribution of child-reported parenting styles. In particular, authoritative parenting was less common than authoritarian and permissive parenting among single-parent than among twoparent families. With respect to younger children, Augustine (2014) used data from the United States and operationalized maternal involvement through maternal-reported measures of the home environment and attitudes about schooling, teacher-reported maternal school involvement, and observer-ratings of mother-child interactions. She found that, within the group of children with low educated mothers, maternal involvement is lower if mothers were not stably married. 
These studies did not control for omitted variable bias. Unobserved variables could, however, influence both parental involvement and children's educational outcomes. In line with this possibility, Sun and Li (2001) showed that marital dissolution was accompanied by a lower amount of parent-child discussions and attendance of school events already before the marital dissolution took place. Contrary to previous research, I apply a research design which controls for omitted variable bias.

Heterogeneity in the Effects of Parental Separation on Father and Mother Involvement

Focusing on the main effects of parental separation on parental involvement may be misleading if the effects of parental separation differ across subpopulations (Amato, 2010). For instance, one may expect father involvement to be less affected by the separation in socioeconomically advantaged families. Families of a higher socio-economic status (SES) have more resources available which may make it easier for fathers to stay highly involved in their children's lives after separation (Mandemakers and Kalmijn, 2014). Furthermore, given that most parents believe that a separation may endanger the educational outcomes of their children, highly educated parents may aim at compensating for the negative consequences of parental separation through their investments (Grätz, 2015). These compensatory responses are likely to be concentrated in high-SES families as reproducing the parental socio-economic status is more at risk due to the disadvantage associated with the separation for children from those families (Breen and Goldthorpe, 1997; Grätz and Bernardi, 2017). For that reason, highSES parents may invest more in the father-child relationship after separation than low-SES parents.

In line with these expectations, but without measuring this mechanism directly, a number of studies have shown that parental separation is more negatively associated with lower educational outcomes in socio-economically disadvantaged families (Albertini and 
Dronkers, 2009; Augustine, 2014; Mandemakers and Kalmijn, 2014; Grätz, 2015; see, however, for opposite findings Bernardi and Radl, 2014; Bernardi and Boertien, 2016). The present study aims at testing whether the effects of parental separation on parental involvement vary by family SES, providing, hence, a test of a mechanism which could explain the finding of socio-economic differences in the effects of parental separation on child education.

Previous research provides some empirical support for this expectation. Studies on the frequency of contact between children and non-resident parents found a higher level of involvement of the non-resident parent in high-SES than in low SES-families with respect to child visitation (Arditti and Keith 1993), father-child contacts (Cheadle et al. 2010; Cooksey and Craig 1998), and overnight stays (Westphal et al. 2014). Analyzing a sample of Belgian children with divorced parents, Bastaits, Ponnet, Van Peer and Mortelmans (2015) found that higher educated fathers had more often an authoritative parenting style. Similarly, Kalmijn (2015a) showed that father involvement was higher in socio-economically advantaged than in socio-economically disadvantaged families for children who experienced parental separation in England, Germany, the Netherlands, and Sweden. None of these studies employed a research design which controlled for omitted variable bias. Hence, it is an open question whether these differences in associations between socio-economically advantaged and disadvantaged families correspond to socio-economic differences in the effects of parental separation on father involvement.

Whilst these arguments lead to expect an interaction between parental separation and social origin with respect to father involvement, Augustine (2014) argued that the consequences of parental separation for maternal involvement varied by family socioeconomic background. She predicted that highly educated mothers had more resources available which allowed them to keep involvement high in their children following separation. In her empirical analysis using data on very young children, she found that maternal parenting 
did depend less on family structure in families with highly educated than in families with low educated mothers. It is interesting to test whether the same pattern is observed in this study.

A further possibility is that the effects of separation on parental involvement vary by child gender. Most previous research did not find gender differences in the associations between parental separation and child outcomes (Powell and Downey, 1997; Amato, 2010). A recent study by Lee and McLanahan (2015), however, found that girls were more negatively affected in their cognitive development when a parent left the household. This finding could be due to gender differences in father involvement following parental separation. If the shared gender between parent and child influences the amount of involvement of a specific parent, separated fathers may have a better relationship with their sons than with their daughters (Powell and Downey, 1997). In line with this expectation, Bastaits et al. (2015) reported that divorced fathers were more involved in the lives of their sons than in the lives of their daughters. In addition, Kalmijn (2015a) showed that boys who experienced parental separation had more contact and judged the relationship with their fathers to have a higher quality than girls who experienced parental separation. These two studies estimate gender differences in samples of children whose parents were separated or divorced. In this study, I test whether the effects of parental separation on parental involvement vary by child gender.

\section{Data and Methods}

Data and Sample

I employ data from the German Socio-Economic Panel Study (SOEP), version 31.1 (DOI: 10.5684/soep.v31.1). The SOEP is a panel study following all members of sampled households and, therefore, allowing me to identify siblings who grow up in the same household (Wagner et al., 2007). Respondents are 16 to 17 years old when they report 
information on parental involvement as part of the youth questionnaire (TNS Infratest Sozialforschung, 2014). Children whose parents died during childhood are dropped from the sample. This results in a sample of 4,478 children born between 1982 and 1997 . This sample is referred to throughout this study as the full sample as it includes all children in the data, some who do not have a sibling and some who have no valid information on their sibling. In the family fixed-effects models, I use a siblings' sample which is derived from the larger full sample. This siblings' sample includes all children who participated in the youth questionnaire and who have at least one sibling who also participated in this questionnaire (2,434 children from 1,107 families).

Variables

Parental separation refers to the family structure of the household in which the child lived the first 15 years of childhood. Parental separation is a dummy variable which is 1 for all children not living continuously 15 years with both parents and 0 for all children living continuously 15 years with both parents. ${ }^{1}$ I rely on information on the first 15 years of childhood because parental involvement is measured when children are around 16 to 17 years old. For that reason, all parental separations occurred prior to children's reports on parental involvement.

I measure parental involvement using child-reported information on the parent-child relationships when children are around 16 to 17 years old. Table 1 gives an overview over the variables used to construct the measures of father and mother involvement (on the full sample). The relationship between the child and his/her mother and father is measured through six questions with respect to each parent. Answers range from 0 to 4 with 0 (never) indicating the lowest and 4 (very often) indicating the highest level of involvement. If a child does not report any information on one parent because he/she says that the parent is missing, I assign a 0 on all variables. 
I use these variables in two principal component analyses to construct separate measures of father and mother involvement (Zumbuehl, Pfann and Dohmen, 2013). Principal component analysis is used because it constructs components which explain most of the variation in the underlying measures and gives an indication of how many components can summarize these measures. ${ }^{2}$ I use the first components of the principal component analyses as the measures of father and mother involvement and standardize these measures to have a mean of 0 and a standard deviation of 1 . These measures of paternal and maternal involvement fulfill my aim to provide measures of the quality of parental involvement. Previous research has shown that parental involvement measured in this or a similar way is associated with positive child outcomes (Harris et al. 1998; Yeung et al., 2002; Chan and Koo, 2011).

\section{[TABLE 1 ABOUT HERE]}

Social origin is a dummy variable which is coded 1 if the child has a parent who obtained the highest German secondary school leaving degree (Abitur, a requirement to study at university) or an equivalent qualification. If none of the parents achieved Abitur (or an equivalent qualification), the variable is 0 . As a robustness check, I employ separate measures of father's and mother's education, both referring to whether the specific parent obtained the Abitur or an equivalent qualification. As an alternative measure of social origin, I use parental EGP class (Erikson and Goldthorpe 1992). I construct a dummy variable which is coded 1 if one of the parents has an occupation in the highest EGP class (class I) or is a large employer (class IVa). The variable is set to 0 if the highest parental occupation is in any other class. In addition, I report results by father's and mother's class based on whether the specific parent has an occupation in classes I or IVa as compared to all other classes. 
The models use child's gender, observed birth order, and birth year as control variables. These variables can be correlated with both parental separation and parental involvement (Sigle-Rushton et al., 2014; Grätz, 2015). Gender is a dummy variable which is 1 for all male children. Birth order is a continuous variable reporting the rank of a child in the family's observed birth order. Period and cohort effects as well as for the influence of maternal age are controlled for via a set of dummy variables for each birth year.

\section{Analytical Strategy}

This study aims at identifying the causal effect of parental separation on parental involvement. Because it is impossible to measure all confounding variables which lead to selection into separation, a research design which controls for omitted variable bias has to be applied. For this purpose previous research has, among others, employed exogenous variations due to changes in divorce laws (Corak, 2001; Gruber, 2004), individual fixedeffects models (Aughinbaugh, Pierret and Rothstein, 2005; Amato and Anthony, 2014), and family fixed-effects models (Sandefur and Wells, 1999; Ermisch and Francesconi, 2001; Björklund and Sundström, 2006; Björklund et al., 2007; Francesconi et al., 2010; SigleRushton et al., 2014; Grätz, 2015). None of these approaches was used to analyze how parental separation affects parental involvement.

I test the parental involvement mechanism using family fixed-effects models. These models use differences in the experience of parental separation between siblings in order to estimate the effect of parental separation on parental involvement. In the case of two siblings, the effect of parental separation is estimated by comparing a sibling who experienced parental separation during childhood with one sibling who lived during childhood continuously with both parents. This difference makes it possible to use the sibling who lived all childhood with both parents as a counterfactual control case for the other sibling. 
The main advantage of this method is that these models control for all characteristics which are shared among siblings which should include the main confounding variables which bias cross-sectional estimates of the association between parental separation and parental involvement (Ermisch and Francesconi, 2001). Examples of such unobserved confounding variables include stable characteristics at the parental level and environmental influences outside of the family.

There are several limitations connected with the use of family fixed-effects models. First, family fixed-effects models estimate the effects of parental separation among siblings and results may not generalize to all children (McLanahan et al., 2013). There is, however, no difference between siblings and the full sample on observed variables within my data (see Table 2 below). Nevertheless, these groups may differ on unobserved variables. In addition, the effect is identified among those siblings differing in terms of parental separation. They may be a selective group and this may further reduce the generalizability of the family fixedeffects estimates. The generalizability is untestable. Whether the effect of parental separation is different for other groups of children can only be estimated by research which uses other methods to identify the causal effect of parental separation.

Second, family fixed-effects models have to assume that there are no confounding variables varying between siblings. Confounding variables which do vary between siblings can bias family fixed-effects estimates (Ermisch and Francesconi, 2001). Parental conflict is an example of such a variable. The sibling who experiences parental separation could experience more parental conflict if the separation is a suddenly occurring event. In most cases, however, parental conflict precedes the actual separation. In this situation, it is unclear which sibling experiences more parental conflict but, on average, it is probably the same amount so that parental conflict is controlled for in this research design. The role of unshared confounding variables is certainly small compared to the influence of these factors. For that reason family fixed-effects estimates are less biased than cross-sectional estimates. In 
addition, even if confounding variables, such as parental conflict, are not completely shared among siblings, family fixed-effects models may be informative about the consequences of delaying separation (Sigle-Rushton et al., 2014).

Descriptive statistics on the full and the siblings' sample are reported in Table 2. The comparison of these statistics allows us to judge how likely it is that the effects estimated on the siblings' sample are generalizable to the full sample. The full and the siblings' sample do not differ on observed variables. There may still be differences in terms of unobserved variables. However, at least based on observed variables, differences between children from one-child and children from more than one-child families are very small.

In addition, Table 2 reports statistics on the variation of the variables within families as well as descriptive statistics on those siblings differing with respect to parental separation, i.e. those children who identify the effect of parental separation in the family fixed-effects models. These comparisons allow us to judge whether these 218 children differ from other siblings on observed characteristics. Table 2 shows that siblings who differ with respect to parental separation are similar to all children in terms of age, gender, and birth order. However, there are differences in terms of social origin reflecting that low-SES children are more likely to experience parental separation. Table 2 also reports differences within families in which siblings differing with respect to parental separation. For instance, the within-family standard deviation of age for this group is 2.46 years.

\section{[TABLE 2 ABOUT HERE]}

In Table A1 in the Supplementary Material, I report results from cross-sectional models on the full and the siblings' sample comparing these estimates to those obtained using the family fixed-effects models. These comparisons show that the cross-sectional estimates estimated on the full and on the siblings' sample are virtually identical. For that reason, 
differences between the family fixed-effects and the cross-sectional estimates are not due to the siblings' sample being selective but are likely to be a result of the differing degree to which these models control for omitted variable bias.

I use multiple imputation with chained equations and 30 imputations in Stata 14.2 to deal with missing values. Additionally, I estimated the models including only non-imputed values. These models led to the same results and are reported in Table 5.

\section{Results}

The Effects of Parental Separation on Father and Mother Involvement

Table 3 reports family fixed-effects models predicting father and mother involvement. Model 1 demonstrates that parental separation has a negative effect on father involvement. The reduction in father involvement as a result of parental separation is statistically significant and substantively large. Parental separation leads, on average, to an around 0.39 of a standard deviation lower father involvement. The negative effect of parental separation on father involvement is stronger than the negative effect of having a by one higher birth order on father involvement.

[TABLE 3 ABOUT HERE]

Whilst father involvement is clearly influenced by parental separation, there is no effect of separation on mother involvement (Model 4). The effect of parental separation on mother involvement is slightly positive. However, the effect size is small and the effect is statistically not significant. 
Table 3 also reports models testing whether the effects of parental separation on parental involvement differ by social origin. These models include the interaction between parental education and parental separation but no main effect since siblings have the same level of parental education. The interaction reports the difference in the effect of parental separation on parental involvement for children with low and those with highly-educated parents. The results are clear: The negative effect of parental separation on father involvement is concentrated in families with a low level of parental education. In those families, parental separation leads to an about 0.50 of a standard deviation lower involvement of the father (Model 2). The negative effect of parental separation on father involvement is canceled out in highly educated families. The interaction between parental separation and parental education is statistically significant and the size of the estimate suggests that the compensation is complete $(-0.50+0.60=0.10)$. Children from families with a high level of parental education do, on average, not experience any reduction in father involvement following parental separation. With respect to mother involvement, there are no social origin differences in the effects of parental separation, for both groups parental separation does not affect maternal involvement.

With respect to child gender, the results reveal a negative effect of parental separation on father involvement for both boys and girls (Model 3). The effect is, however, less pronounced for boys. The interaction between parental separation and child gender is statistically significant but the size of the estimate suggests that the compensation is not complete $(-0.53+0.29=-0.24)$. Nevertheless, these models show that parental separation leads to a stronger reduction in father involvement for girls than for boys. ${ }^{3}$ With respect to mother involvement, there is no indication of any gender differences in separation effects. 
Understanding the Stratification of the Effects of Parental Separation on Father Involvement

A main finding of the analysis is the socio-economic heterogeneity in the consequences of parental separation for father involvement. In order to test the robustness of this finding and to better understand why this heterogeneity occurs, I test the socio-economic differential in separation effects using several alternative measures of social origin. In addition to testing variation by the highest level of parental education, Table 4 reports heterogeneity in separation effects with respect to father's and mother's education as well as with respect to the highest parental, father's, and mother's class.

All models reveal a concentration of the negative effect of parental separation on father involvement in socio-economically disadvantaged families. The only case in which the interaction between social origin and parental separation is statistically not significant is the model using maternal occupation as an indicator of social origin. Even in this case, however, the effect goes in the same direction. With respect to all other indicators, there is clear evidence that the negative effect of parental separation on father involvement is brought about only in low-SES families.

In addition to testing the robustness of the results, the comparison of indicators of maternal and paternal resources allows us to analyze whether maternal or paternal resources are more important for the compensation to occur. The results suggest that the resources of the father may be more important. This is especially apparent with respect to social class as a measure of social origin. In that case, the estimate of the interaction is considerably larger for the class position of the father than for the class position of the mother in both the models which enter each indicator separately and the models which include both indicators simultaneously. Results are less clear with respect to father's and mother's education. In the separate models, both interactions have nearly the same size. If both variables are included in the same model, however, both interactions become statistically insignificant as a result of 
both variables being highly collinear. Since the size of the interaction between parental separation and father's education is larger than the size of the interaction between parental separation and mother's education, this can be understood as pointing in the direction that father's resources are more influential in reducing the negative effect of parental separation on father involvement. Further research is, however, needed to substantiate this claim.

[TABLE 4 ABOUT HERE]

\section{Robustness Checks}

The main specification above reported estimates after multiply imputing missing values. I also estimated the models using only non-imputed values (Table 5). These results are fully in line with those reported above, even though statistical significance and effect sizes are slightly lower. In any case, all conclusions of this study are confirmed by the analysis using only nonimputed values.

\section{[TABLE 5 ABOUT HERE]}

A further issue is that the principal component analysis indicated that mother involvement (but not father involvement) also loaded on a second component. In order to test whether this second component of mother involvement is affected by parental separation, I estimated the effect of parental separation on this second component of mother involvement (Table 6). The results show, in line with the findings for the first component, that parental separation does not affect maternal involvement. 


\section{Conclusion}

This article uses data on a recent cohort of adolescents in Germany and family fixed-effects models in order to estimate the consequences of parental separation for father and mother involvement. On average, parental separation leads to an around 2/5 of a standard deviation decrease in father involvement. Contrary to that, mother involvement is unaffected by parental separation. There is, however, important heterogeneity in the father-child relationship following parental separation. The negative effect of parental separation on father involvement is only found in low-SES families. In addition, the negative effect is less pronounced for boys than for girls.

These findings are largely in line with results from previous research which did not control for omitted variable bias. For instance, several studies documented less father involvement as a result of parental separation in low-SES compared to high-SES families (Arditti and Keith, 1993; Cooksey and Craig, 1998; Cheadle et al., 2010; Westphal et al., 2014; Bastaits et al., 2015; Kalmijn, 2015a). Similar results were produced by the research on the relationships between divorced parents and their adult children (Kalmijn, 2015b). Some previous studies found girls to have a worse relationship with their divorced fathers than boys (Bastaits et al. 2014; Kalmijn, 2015a). I found similar gender differences applying family fixed-effects models.

The results of this study have implications for research on the consequences of parental separation in general. First, they show that parental involvement is an important element of the separation process as father involvement is indeed affected by parental separation. Further efforts to understand the parental separation penalty for children's outcomes should take into account father involvement. Second, this study's findings provide further support to the claim that the consequences of parental separation vary by child gender and by family socioeconomic status. Previous research analyzed socio-economic heterogeneity in the associations 
between parental separation and child education (Albertini and Dronkers, 2009; Augustine, 2014; Bernardi and Radl, 2014; Mandemakers and Kalmijn, 2014; Grätz, 2015; Bernardi and Boertien, 2016). However, this is the first study to show that the role of a mechanism underlying this relationship varies by SES. Hence, the present study provides a potential explanation why parental separation affects children's educational outcomes more negatively in low- than in high-SES families.

This study does, however, not show that father involvement is the main mechanism underlying the negative effects of parental separation on child outcomes. Demonstrating that this is indeed the case is an important but difficult task for future research. Such an analysis has, first, to identify a causal effect of parental separation on a child outcome, second, to identify a causal effect of parental separation on parental involvement, and, third, it needs also to show that the changes in parental involvement following parental separation bring indeed about the negative effect of parental separation on child education (Imai, Keele, Tingley and Yamamoto, 2011).

Further research should also take into account the other mechanisms hypothesized to underlie the negative effect of parental separation on child outcomes, for instance children's experience of stress (Amato, 1993). Similarly, the amount of socio-economic resources available to the child may be reduced following parental separation and this may negatively influence child outcomes (Thomson, Hanson, and McLanahan, 1994). A complete picture of the mechanisms underlying the parental separation penalty requires operationalizing different mechanisms in the same analysis employing research designs which control for omitted variable bias.

A further topic which could be investigated is the role of age at separation. Previous research has argued that the effects of parental separation on child outcomes differ by children's age at separation (Cavanagh and Hutton, 2008; Fomby and Bosick, 2013; Sigle- 
Rushton et al., 2014). A similar finding could occur with respect to parental involvement. Such an analysis requires measures of parental involvement observed at different ages.

To sum up, further research is needed to fully understand the channels through which parental separation affects child development. This study shows that parental involvement should be taken into account in these efforts. At the same time, research has to pay attention to the underlying heterogeneity in the consequences of parental separation. 


\section{NOTES}

1. This definition of parental separation includes children born into single parent households. Around $86 \%$ of the children who experienced parental separation lived more years with the mother than with the father after separation. It is likely that more involved fathers are more likely to live with the child. Controlling for the postseparation living arrangement would, hence, introduce bias.

2. Alpha reliabilities are .86 for father and .74 for mother involvement. For both measures, father/mother takes initiative to discuss problems contributes the least to the first component whilst all other items contribute roughly equally. Mother involvement (but not father involvement) loads also on a second component (to which mainly mother takes initiative to discuss problems contributes). The results of models predicting the effect of parental separation on this second component do not differ from those for the first component (Table 6).

3. Gender differences in the effect of parental separation on father involvement could vary by social origin. I tested this possibility but there is not enough statistical power in the sample to produce conclusive results (Table A2 in the Supplementary Material). 


\section{REFERENCES}

Albertini, M. and Dronkers, J. (2009). Effects of divorce on children's educational attainment in a Mediterranean and catholic society. European Societies, 11, 137-159.

Amato, P. R. (1993). Children's adjustment to divorce: theories, hypotheses, and empirical support. Journal of Marriage and Family, 55, 23-38.

Amato, P. R. (2010). Research on divorce: continuing trends and new developments. Journal of Marriage and Family, 72, 650-666.

Amato, P. R. and Anthony, C. J. (2014). Estimating the effects of parental divorce and death with fixed effects models. Journal of Marriage and Family, 76, 370-386.

Amato, P. R. and Gilbreth, J. G. (1999). Nonresident fathers and children's well-being: a meta-analysis. Journal of Marriage and Family, 61, 557-573.

Arditti, J. and Keith, T. (1993). Visitation frequency, child support payment, and the fatherchild relationship postdivorce. Journal of Marriage and Family, 55, 699-712.

Astone, N. M. and McLanahan, S. (1991). Family structure, parental practices, and high school completion. American Sociological Review, 56, 309-320.

Aughinbaugh, A., Pierret, C. and Rothstein, D. (2005). The impact of family structure transitions on youth achievement: evidence from the children of the NLSY79. Demography, 42, 447-468.

Augustine, J. M. (2014). Maternal education and the unequal significance of family structure for children's early achievement. Social Forces, 93, 687-718.

Bastaits, K., Ponnet, K., Van Peer, C. and Mortelmans, D. (2015). The parenting styles of divorced fathers and their predictors. Journal of Social and Personal Relationships, 32, $557-579$.

Bernardi, F. and Boertien, D. (2016). Understanding heterogeneity in the effects of parental separation on educational attainment in Britain: do children from lower educational backgrounds have less to lose? European Sociological Review 32, 807-819. 
Bernardi, F. and Radl, J. (2014). Parental separation, social origin and educational attainment: the long-term consequences of divorce for children. Demographic Research, 30, 16531680.

Björklund, A., Ginter, D. K. and Sundström, M. (2007). Family structure and child outcomes in the USA and Sweden. Journal of Population Economics, 20, 183-201.

Björklund, A. and Sundström, M. (2006). Parental separation and children's educational attainment: a siblings analysis on Swedish register data. Economica, 73, 605-624.

Breen, R. and Goldthorpe, J. (1997). Explaining educational differentials: towards a formal ration action theory. Rationality and Society, 9, 275-305.

Carlson, M. J. (2006). Family structure, father involvement, and adolescent behavioral outcomes. Journal of Marriage and Family, 68, 137-154.

Cavanagh, S. E. and Huston, A. C. (2008). The timing of family instability and children's social development. Journal of Marriage and Family, 70, 1258-1269.

Chan, T. W. and Koo, A. (2011). Parenting style and youth outcomes in the UK. European Sociological Review, 27, 385-399.

Cheadle, J., Amato, P. R. and King, V. (2010). Patterns of nonresident father contact. Demography, 47, 205-225.

Coleman, J. (1988). Social capital in the creation of human capital. American Journal of Sociology, 94, S95-S120.

Cooksey, E. C. and Craig, P. H. (1998). Parenting from a distance: the effects of paternal characteristics on contact between nonresidential fathers and their children. Demography, 35, 187-201.

Corak, M. (2001). Death and divorce: the long-term consequences of parental loss on adolescents. Journal of Labor Economics, 19, 682-715.

Erikson, R. and Goldthorpe, J. H. (1992). The Constant Flux: A Study of Class Mobility in Industrial Societies. Oxford: Clarendon Press. 
Ermisch, J. and Francesconi, M. (2001). Family structure and children's achievements. Journal of Population Economics, 14, 249-270.

Fomby, P. and Bosick, S. J. (2013). Family instability and the transition to adulthood. Journal of Marriage and Family, 75, 1266-1287.

Francesconi, M., Jenkins, S. P. and Siedler, T. (2010). Childhood family structure and schooling outcomes: evidence for Germany. Journal of Population Economics, 23, $1201-1231$.

Furstenberg, F. F., Nord, C. W., Peterson, J. L. and Zill, N. (1983). The life course of children of divorce: marital disruption and parental contact. American Sociological Review, 48, 656-668.

Gähler, M., Jonsson, J. O. and Låftman, S. B. (2009). The importance of being present: the influence of 'absent' parents and 'present' step-parents on children's educational attainment. Paper presented at the RC28 Spring Meeting (International Sociological Association), Beijing.

Grätz, M. (2015). When growing up without a parent does not hurt: parental separation and the compensatory effect of social origin. European Sociological Review, 31, 546-557.

Grätz, M. and Bernardi, F. (2017). Parental responses to disadvantageous life events: the month of birth penalty in England. In Erola, J. and Kilpi-Jakonen, E. (Eds.), Social Inequality Across the Generations: The Role of Resource Compensation and Multiplication in Resource Accumulation. Cheltenham, Edward Elgar, pp.68-88.

Gruber, J. (2004). Is making divorce easier bad for children? The long-run implications of unilateral divorce. Journal of Labor Economics, 22, 799-833.

Harris, K. M., Furstenberg, F. F. and Marmer, J. K. (1998). Paternal involvement with adolescents in intact families: the influence of fathers over the life course. Demography, 35, 201-216. 
Imai, K., Keele, L., Tingley, D. and Yamamoto, T. (2011). Unpacking the black box of causality: learning about causal mechanisms from experimental and observational studies. American Political Science Review, 105, 765-789.

Jonsson, J. O. and Gähler, M. (1997). Family dissolution, family reconstitution, and children's educational careers: recent evidence for Sweden. Demography, 34, 277-293.

Kalmijn, M. (2015a). Father-child relations after divorce in four European countries: patterns and determinants. Comparative Population Studies, 40, 251-276.

Kalmijn, M. (2015b). How childhood circumstances moderate the long-term impact of divorce on father-child relationships. Journal of Marriage and Family, 77, 921-938.

Kaushal, N., Magnuson, K. and Waldfogel, J. (2011). How is family income related to investments in children's learning? In Duncan, G. and Murnane, R. (Eds.), Whither Opportunity? Rising Inequality, Schools, and Children's Life Chances. New York, NY: Russell Sage Foundation, pp. 187-206.

King, V. and Heard, H. E. (1999). Nonresident father visitation, parental conflict, and mother's satisfaction: what's best for child well-being? Journal of Marriage and Family, 61, 385-396.

Lee, D. and McLanahan, S. (2015). Family structure transitions and child development: instability, selection, and population heterogeneity. American Sociological Review, 80, $738-763$.

Mandemakers, J. and Kalmijn, M. (2014). Do mother's and father's education condition the impact of parental divorce on child well-being? Social Science Research, 44, 187-199.

McLanahan, S., Tach, L. and Schneider, D. (2013). The causal effects of father absence. Annual Review of Sociology, 39, 399-427.

Mott, F. (1990). When is a father really gone? Paternal-child contact in father-absent homes. Demography, 27, 499-517. 
Powell, B. and Downey, D. (1997). Living in single-parent households: an investigation of the same-sex hypothesis. American Sociological Review, 62, 521-539.

Sandefur, G. S. and Wells, T. (1999). Does family structure really influence educational attainment? Social Science Research, 28, 331-357.

Seltzer, J. A. (1991). Relationships between fathers and children who live apart: the father's role after separation. Journal of Marriage and Family, 53, 79-102.

Seltzer, J. A. and Bianchi, S. M. (1988). Children's contact with absent parents. Journal of Marriage and the Family, 50, 663-677.

Sigle-Rushton, W., Lyngstad, T. H., Andersen, P. L. and Kravdal, Ø. (2014). Proceed with caution? Parents' union dissolution and children's educational achievements. Journal of Marriage and Family, 76, 161-174.

Sun, Y. and Li, Y. (2001). Marital disruption, parental investment, and children's academic achievement. Journal of Family Issues, 22, 27-62.

Thomson, E., Hanson, T. L. and McLanahan, S. S. (1994). Family structure and child wellbeing: economic resources vs. parental behavior. Social Forces, 73, 221-242.

TNS Infratest Sozialforschung. (2014). SOEP 2014: Erhebungsinstrumente 2014 (Welle 31) des Sozio-oekonomischen Panels: Jugendfragebogen, Altstichproben. SOEP Survey Papers Series A, No. 238.

Wagner, G. G., Frick, J. R. and Schupp, J. (2007). The German Socio-Economic Panel Study (SOEP): scope, evolution and enhancements. Schmollers Jahrbuch, 127, 139-169.

Westphal, S. K., Poortman, A.-R. and van der Lippe, T. (2014). Non-resident father-child contact across divorce cohorts: the role of father involvement during marriage. European Sociological Review, 30, 444-456.

Yeung, W. J., Linver, M. R. and Brooks-Gunn, J. (2002). How money matters for young children's development: parental investment and family processes. Child Development, 73, $1861-1879$. 
Zumbuehl, M., Pfann, G. and Dohmen, T. (2013). Parental investments and the intergenerational transmission of economic preferences and attitudes. IZA Discussion Paper, No. 7476. 


\section{TABLES}

Table 1. Variables used to construct the measures of father and mother involvement

\begin{tabular}{|c|c|c|c|c|c|}
\hline Variable & Mean & SD & Min. & Max. & $N$ \\
\hline \multicolumn{6}{|l|}{ Father involvement } \\
\hline $\begin{array}{l}\text { Talk to father about own } \\
\text { experiences }\end{array}$ & 2.14 & 1.13 & 0 & 4 & 4,180 \\
\hline $\begin{array}{l}\text { Father takes initiative to } \\
\text { discuss problems }\end{array}$ & 1.83 & 1.09 & 0 & 4 & 4,175 \\
\hline $\begin{array}{l}\text { Father asks about } \\
\text { opinion before making } \\
\text { decisions }\end{array}$ & 2.31 & 1.27 & 0 & 4 & 4,171 \\
\hline $\begin{array}{l}\text { Problems with father are } \\
\text { solved together }\end{array}$ & 2.26 & 1.19 & 0 & 4 & 4,145 \\
\hline $\begin{array}{l}\text { Father asks about } \\
\text { opinion about family }\end{array}$ & 2.09 & 1.21 & 0 & 4 & 4,148 \\
\hline $\begin{array}{l}\text { Father gives reasons for } \\
\text { decisions }\end{array}$ & 2.22 & 1.21 & 0 & 4 & 4,160 \\
\hline \multicolumn{6}{|l|}{ Mother involvement } \\
\hline $\begin{array}{l}\text { Talk to mother about } \\
\text { own experiences }\end{array}$ & 2.74 & 0.93 & 0 & 4 & 4,268 \\
\hline $\begin{array}{l}\text { Mother takes initiative } \\
\text { to discuss problems }\end{array}$ & 2.26 & 0.99 & 0 & 4 & 4,262 \\
\hline $\begin{array}{l}\text { Mother asks about } \\
\text { opinion before making } \\
\text { decisions }\end{array}$ & 2.65 & 1.09 & 0 & 4 & 4,257 \\
\hline $\begin{array}{l}\text { Problems with mother } \\
\text { are solved together }\end{array}$ & 2.62 & 1.01 & 0 & 4 & 4,236 \\
\hline $\begin{array}{l}\text { Mother asks about } \\
\text { opinion about family }\end{array}$ & 2.47 & 1.05 & 0 & 4 & 4,245 \\
\hline $\begin{array}{l}\text { Mother gives reasons for } \\
\text { decisions }\end{array}$ & 2.56 & 1.04 & 0 & 4 & 4,251 \\
\hline
\end{tabular}

Note: Descriptive statistics refer to the full, non-imputed sample. This sample is used to construct the measures of father and mother involvement.

Source: German Socio-Economic Panel Study (SOEP), v31.1. DOI: 10.5684/soep.v31.1. 
Table 2. Descriptive statistics

\begin{tabular}{|c|c|c|c|c|c|c|c|c|c|c|c|c|c|}
\hline \multirow[b]{2}{*}{ Variable } & \multicolumn{3}{|c|}{$\begin{array}{l}\text { Full sample (including } \\
\text { children without a } \\
\text { sibling in the data) }\end{array}$} & \multicolumn{5}{|c|}{$\begin{array}{l}\text { Siblings sample (all children with at least one } \\
\text { sibling in the data) }\end{array}$} & \multicolumn{5}{|c|}{$\begin{array}{l}\text { Siblings who differ on the parental } \\
\text { separation variable }\end{array}$} \\
\hline & Mean & $S D$ & $N$ & Mean & $S D$ & $S D_{\text {within }}$ & $S D_{\text {between }}$ & $N$ & Mean & $S D$ & $S D_{\text {within }}$ & $S D_{\text {between }}$ & $N$ \\
\hline Age (in 2014) & 23.51 & 4.70 & 4,478 & 24.00 & 4.39 & 1.95 & 4.01 & 2,434 & 24.54 & 4.29 & 2.46 & 3.65 & 218 \\
\hline Male & 0.50 & 0.50 & 4,478 & 0.49 & 0.50 & 0.36 & 0.35 & 2,434 & 0.47 & 0.50 & 0.37 & 0.34 & 218 \\
\hline $\begin{array}{l}\text { High parental } \\
\text { education }\end{array}$ & 0.30 & 0.46 & 4,458 & 0.31 & 0.46 & $-^{\mathrm{a}}$ & $-^{\mathrm{a}}$ & 2,430 & 0.18 & 0.38 & $-^{\mathrm{a}}$ & $-^{\mathrm{a}}$ & 217 \\
\hline High father's education & 0.24 & 0.43 & 4,240 & 0.24 & 0.43 & $--^{\mathrm{a}}$ & $--^{\mathrm{a}}$ & 2,356 & 0.15 & 0.36 & $-{ }^{\mathrm{a}}$ & $--^{\mathrm{a}}$ & 202 \\
\hline $\begin{array}{l}\text { High mother's } \\
\text { education }\end{array}$ & 0.20 & 0.40 & 4,403 & 0.21 & 0.41 & $-^{\mathrm{a}}$ & $--^{\mathrm{a}}$ & 2,414 & 0.12 & 0.32 & $--^{a}$ & $-{ }^{\mathrm{a}}$ & 216 \\
\hline High parental class & 0.18 & 0.38 & 4,121 & 0.17 & 0.38 & $-^{\mathrm{a}}$ & $-^{\mathrm{a}}$ & 2,369 & 0.10 & 0.29 & $-^{\mathrm{a}}$ & $-^{\mathrm{a}}$ & 209 \\
\hline High father's class & 0.17 & 0.38 & 3,875 & 0.17 & 0.37 & $-{ }^{\mathrm{a}}$ & $-{ }^{\mathrm{a}}$ & 2,288 & 0.07 & 0.26 & $-{ }^{\mathrm{a}}$ & $-{ }^{\mathrm{a}}$ & 205 \\
\hline High mother's class & 0.12 & 0.33 & 3,529 & 0.13 & 0.33 & $-{ }^{\mathrm{a}}$ & $-{ }^{\mathrm{a}}$ & 2,145 & 0.07 & 0.26 & $-{ }^{\mathrm{a}}$ & $-{ }^{\mathrm{a}}$ & 189 \\
\hline Parental separation & 0.25 & 0.43 & 4,478 & 0.19 & 0.40 & 0.15 & 0.37 & 2,434 & 0.50 & 0.50 & 0.49 & 0.10 & 218 \\
\hline $\begin{array}{l}\text { Years lived with both } \\
\text { parents }\end{array}$ & 12.82 & 4.45 & 4,478 & 13.37 & 3.91 & 1.58 & 3.57 & 2,434 & 11.20 & 5.32 & 4.53 & 2.76 & 218 \\
\hline Birth order & 1.76 & 0.90 & 4,478 & 1.88 & 0.95 & 0.64 & 0.64 & 2,434 & 1.96 & 0.88 & 0.72 & 0.51 & 218 \\
\hline Father involvement & 0.00 & 1.00 & 4,077 & 0.04 & 0.96 & 0.50 & 0.85 & 2,253 & -0.16 & 1.16 & 0.64 & 1.00 & 193 \\
\hline Mother involvement & 0.00 & 1.00 & 4,183 & 0.00 & 0.99 & 0.62 & 0.79 & 2,295 & 0.00 & 1.03 & 0.69 & 0.81 & 204 \\
\hline
\end{tabular}

Note: Descriptive statistics refer to the non-imputed variables.

a These variables do not vary between siblings.

Source: German Socio-Economic Panel Study (SOEP), v31.1. DOI: 10.5684/soep.v31.1. 
Table 3. Family fixed-effects estimates of the effects of parental separation on father and mother involvement

\begin{tabular}{|c|c|c|c|c|c|c|}
\hline \multirow[b]{2}{*}{ Variable } & \multicolumn{3}{|c|}{ Father involvement } & \multicolumn{3}{|c|}{ Mother involvement } \\
\hline & (1) & (2) & (3) & (4) & (5) & (6) \\
\hline Parental separation & $-0.39 * *$ & $-0.50 * *$ & $-0.53 * *$ & 0.02 & -0.03 & 0.01 \\
\hline Male & 0.05 & 0.04 & -0.01 & $-0.22 * *$ & $-0.23 * *$ & $-0.23 * *$ \\
\hline \multirow[t]{2}{*}{ Birth order } & -0.05 & -0.05 & -0.06 & -0.04 & -0.04 & -0.04 \\
\hline & $(0.05)$ & $(0.05)$ & $(0.05)$ & $(0.06)$ & $(0.06)$ & $(0.06)$ \\
\hline Parental separation $\times$ & & $0.60 *$ & & & 0.30 & \\
\hline Parental separation $\times$ & & & $0.29 *$ & & & 0.01 \\
\hline Male & & & $(0.13)$ & & & $(0.13)$ \\
\hline$N$ & 2,434 & 2,434 & 2,434 & 2,434 & 2,434 & 2,434 \\
\hline
\end{tabular}

Note: All models control for birth year. Cluster-robust standard errors in parentheses. There are 218 children who differ from at least one sibling on the parental separation variable.

Significance levels (two-tailed tests): ${ }^{\dagger} p<.10,{ }^{*} p<.05, * * p<.01$.

Source: German Socio-Economic Panel Study (SOEP), v31.1. DOI: 10.5684/soep.v31.1. 
Table 4. Family fixed-effects estimates of the effects of parental separation on father involvement, different measures of social origin

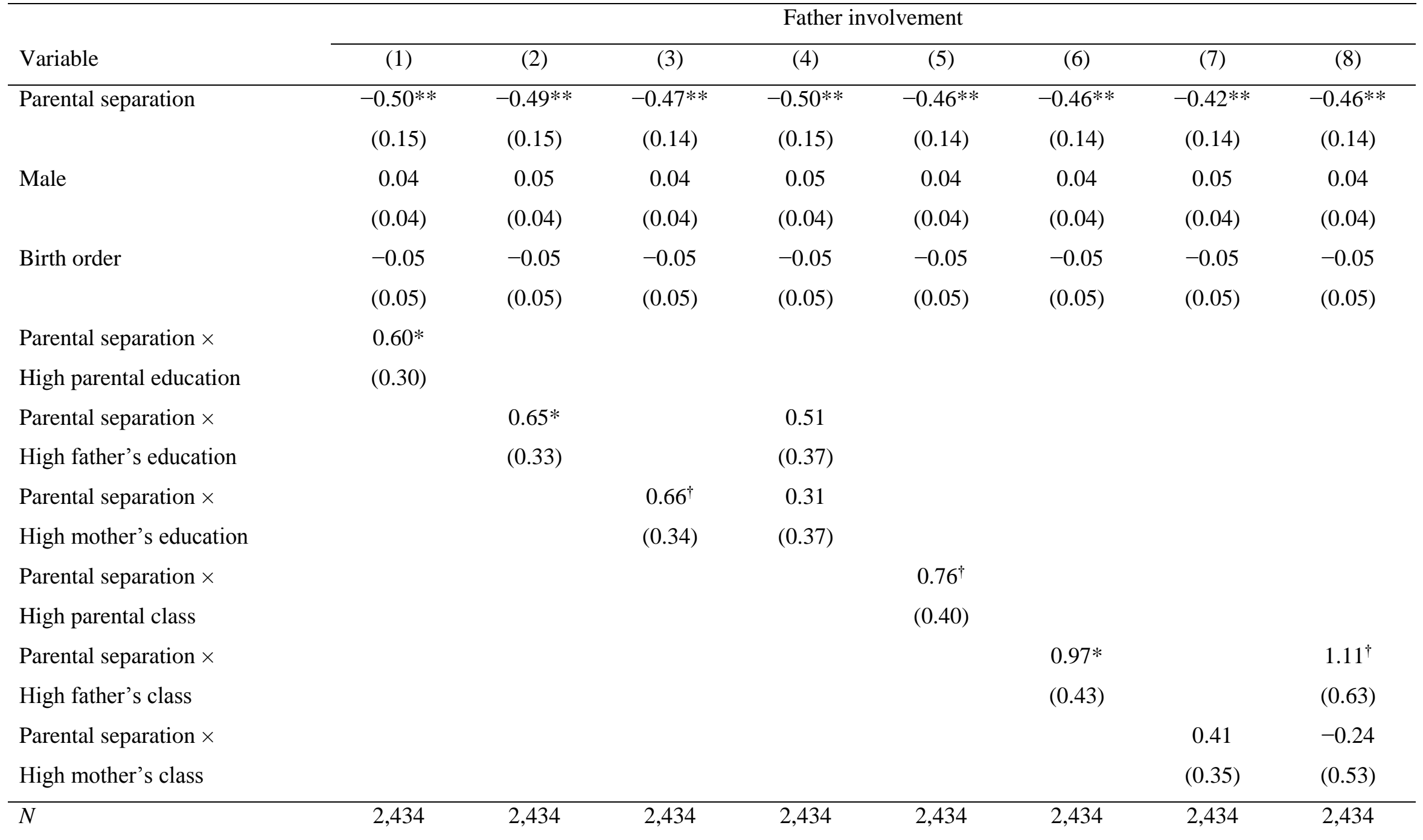

Note: All models control for birth year. Cluster-robust standard errors in parentheses. There are 218 children who differ from at least one sibling on the parental separation variable.

Significance levels (two-tailed tests): ${ }^{\dagger} p<.10, * p<.05, * * p<.01$

Source: German Socio-Economic Panel Study (SOEP), v31.1. DOI: 10.5684/soep.v31.1. 
Table 5. Family fixed-effects estimates of the effects of parental separation on father and mother involvement, non-imputed sample

\begin{tabular}{|c|c|c|c|c|c|c|}
\hline \multirow[b]{2}{*}{ Variable } & \multicolumn{3}{|c|}{ Father involvement } & \multicolumn{3}{|c|}{ Mother involvement } \\
\hline & (1) & (2) & (3) & (4) & (5) & (6) \\
\hline \multirow[t]{2}{*}{ Parental separation } & $-0.24^{\dagger}$ & $-0.31^{*}$ & $-0.37 * *$ & -0.05 & -0.09 & -0.05 \\
\hline & $(0.13)$ & $(0.15)$ & $(0.14)$ & $(0.14)$ & $(0.17)$ & $(0.16)$ \\
\hline \multirow[t]{2}{*}{ Male } & 0.04 & 0.04 & -0.01 & $-0.23 * *$ & $-0.23 * *$ & $-0.23 * *$ \\
\hline & $(0.04)$ & $(0.04)$ & $(0.04)$ & $(0.05)$ & $(0.05)$ & $(0.05)$ \\
\hline \multirow[t]{2}{*}{ Birth order } & -0.04 & -0.04 & -0.04 & -0.04 & -0.04 & -0.04 \\
\hline & $(0.05)$ & $(0.05)$ & $(0.05)$ & $(0.06)$ & $(0.06)$ & $(0.06)$ \\
\hline Parental separation $x$ & & $0.44^{\dagger}$ & & & 0.23 & \\
\hline High parental education & & $(0.26)$ & & & $(0.29)$ & \\
\hline \multirow[t]{2}{*}{ Parental separation $\times$ Male } & & & $0.27 *$ & & & 0.01 \\
\hline & & & $(0.12)$ & & & $(0.14)$ \\
\hline$N$ & 2,253 & 2,250 & 2,253 & 2,295 & 2,292 & 2,295 \\
\hline
\end{tabular}

Note: All models control for birth year. Cluster-robust standard errors in parentheses.

Significance levels (two-tailed tests): ${ }^{\dagger} p<.10, * p<.05, * * p<.01$.

Source: German Socio-Economic Panel Study (SOEP), v31.1. DOI: 10.5684/soep.v31.1. 
Table 6. Family fixed-effects estimates of the effects of parental separation on mother involvement, second component of the principal component analysis

\begin{tabular}{|c|c|c|c|}
\hline \multirow[b]{2}{*}{ Variable } & \multicolumn{3}{|c|}{ Mother involvement, second component } \\
\hline & (1) & (2) & (3) \\
\hline \multirow[t]{2}{*}{ Parental separation } & -0.19 & -0.18 & -0.15 \\
\hline & $(0.14)$ & $(0.16)$ & $(0.15)$ \\
\hline \multirow[t]{2}{*}{ Male } & $-0.21 * *$ & $-0.21 * *$ & $-0.19 * *$ \\
\hline & $(0.05)$ & $(0.05)$ & $(0.06)$ \\
\hline \multirow[t]{2}{*}{ Birth order } & -0.05 & -0.05 & -0.04 \\
\hline & $(0.06)$ & $(0.06)$ & $(0.06)$ \\
\hline \multirow[t]{2}{*}{ Parental separation $\times$ High parental education } & & -0.06 & \\
\hline & & $(0.32)$ & \\
\hline \multirow[t]{2}{*}{ Parental separation $\times$ Male } & & & -0.09 \\
\hline & & & $(0.14)$ \\
\hline$N$ & 2,434 & 2,434 & 2,434 \\
\hline
\end{tabular}

Note: All models control for birth year. Cluster-robust standard errors in parentheses.

Significance levels (two-tailed tests): ${ }^{\dagger} p<.10,{ }^{*} p<.05, * * p<.01$.

Source: German Socio-Economic Panel Study (SOEP), v31.1. DOI: 10.5684/soep.v31.1. 